\section{EREM 76/3}

Journal of Environmental Research, Engineering and Management Vol. 76 / No.3 / 2020 pp. $62-70$

DOI 10.5755/j01.erem.76.3.24220
Natural Zeolites of Eastern Transbaikalia in Technologies for Mining Enterprises Wastewater Treatment

\title{
Natural Zeolites of Eastern Transbaikalia in Technologies for Mining Enterprises Wastewater Treatment
}

\section{Vitaliy Vitalievich Milyutin, Nataliya Anatolevna Nekrasova}

Institute of Physical Chemistry and Electrochemistry named after A. N. Frumkin, Moscow, 119071,

Leninsky Prospect, 31, bldg. 4

Konstantin Konstantinovich Razmakhnin*

Mining Institute named after A. N. Chinakala SB RAS, Chita Branch, Chita, 672039, Alexandro-Zavodskaya str. 30

\section{Alisa Nikolaevna Khatkova}

Transbaikal State University, Chita, 672039, ul. Alexandro-Zavodskaya 30

*Corresponding author: constantin-const@mail.ru

The possibilities of conditioning acidified wastewater from mining enterprises by natural zeolites of deposits in East Transbaikalia were studied. Sorption characteristics of various natural and synthetic zeolites in relation to strontium and cesium radionuclides were determined to evaluate the possibility of their application for the purification of radioactively contaminated technogenic and natural waters. The ability of natural zeolites to selectively adsorb the heavy metal ions was investigated. An experimental study was made on the possibility of neutralizing acidic media with zeolites. The kinetic dependencies were obtained to evaluate the ion exchange rate on the natural zeolites. The impact of exchanging cations and the defining mineral's structure on the exchange rate was studied. The instantaneous adsorption interaction rate values were determined. The possibility of ${ }^{90} \mathrm{Sr}$ and $\mathrm{Ca}^{2+}$ ions sorption from the simulated solutions of industrial wastewater was investigated.

Keywords: natural zeolites, sorption, wastewater 


\section{Introduction}

Mining wastewater has a significant impact on the state of the natural environment components. In connection with the rapid development of the mining industry in Russia, which causes an ever-increasing production output and the continuous generation of large production waste volumes, the amount of wastewater from concentration plants, quarries, pits, and mines shows a constant upward trend. To this list, one can add the effluents of boiler houses and thermal power plants of mining and processing enterprises, effluents of atmospheric waters, as well as mine and quarry waters. Moreover, the wastewater of mining enterprises is often characterized by a high content of metal ions, various chemical compounds (including flotation reagents), colloidal mineral particles, oil products, organic and bacterial substances, toxic and radioactive elements. The basic properties of wastewater from mining enterprises include the increased alkalinity, acidity, hardness, the high content of salts, and suspended solids (turbidity).

A large number of studies have been devoted to the purification of wastewater from mining enterprises from non-ferrous metal ions, chemical compounds, suspended mineral particles and oil products (Kuznetsov et al., 1974; Ryabchikov, 2008; Milyutin et al., 1993; Milyutin et al., 2012). The vast reserves of zeolite-bearing rocks (about $70 \%$ of the total Russian reserves) are concentrated in East Transbaikalia. However, the application of natural zeolites from its deposits for the removal of radioactive elements from the industrial water at the mining enterprises, wastewater of the operating power supply enterprises of the mining complex, and those to be commissioned yet remain a poorly addressed issue.

In recent years, the proposed concept of the application of low-power nuclear power plants for the mining enterprises located in the remote areas of the country is gaining more and more supporters (Saneev et al., 2011; Melnikov et al., 2014; Melnikov et al., 2015). An essential issue of the use of atomic energy in the mining sector is ensuring the operational safety, including the treatment of the industrial wastewater from longlived and highly toxic radionuclides of cesium, strontium, and strontium cobalt, plutonium, and others.
To date, the methods based on sorption, precipitation, and membrane processes have been most often used to separate radionuclides from solutions (Saneev et al., 2011; Melnikov et al., 2014; Melnikov et al., 2015, Kuznetsov et al., 1974; Ryabchikov, 2008; Milyutin et al., 1993; Milyutin et al., 2012; Pavlenko, 2000; Khatkova et al., 2014; Shushkov et al., 2006; Chelishev, 1987; Yusupov, 1985). The choice of a particular method depends on the chemical and radionuclide composition of liquid radioactive waste and is defined by the state of radionuclides in solution.

For the purification of natural and wastewaters from radionuclides, sorption methods are widely used (Kuznetsov et al., 1974; Ryabchikov, 2008; Milyutin et al., 2012). Organic ion-exchange resins as well as inorganic sorbents, both of the synthetic and natural origin (Milyutin et al., 1993) have been used for the sorbents. The main advantage of the sorbents based on natural materials is their availability and low cost. Among the natural sorbents, various aluminosilicate minerals, in particular, natural clays of different compositions, have been most widely used for the purification of solutions from radionuclides (Kuznetsov Y.V. et al., 1974). This type of sorbent has been used primarily to separate the ionic forms of cesium and strontium radionuclides. Sorption of these radionuclides occurs due to the presence of the exchangeable ions of sodium, potassium, magnesium, calcium, and others in the structure of the sorbents. Modification of the aluminosilicate minerals using chemical or thermal methods results in the improved ion-exchange capabilities.

In this work, we studied the possibilities of conditioning acidified effluents of mining enterprises by natural zeolites of East Transbaikalia deposits. The acidic wastewater neutralization issue is crucial for the majority of metal-bearing raw material processing enterprises. It is caused by the presence in the ore of the secondary iron and zinc sulfate minerals in the form of melanterite $\mathrm{FeSO} 4 \cdot 7 \mathrm{H}_{2} \mathrm{O}$, fibroferrite $\mathrm{FeSO}_{4}$ $(\mathrm{OH}) \cdot 5 \mathrm{H}_{2} \mathrm{O}$, and zinc melanterite $(\mathrm{Zn}, \mathrm{Cu}) \mathrm{SO}_{4} \cdot 7 \mathrm{H}_{2} \mathrm{O}$.

Due to the high solubility of iron (II) and zinc sulfates in water, their bulk quantity moves into the liquid phase of the pulp as early as the ore washing process. The 
subsequent hydrolysis leads to a decrease in $\mathrm{pH}$ to 3.5-4.5, and the complete neutralization in the system could be achieved using natural zeolites.

It is known that the neutralization of acidic effluents with natural zeolites is associated with the successive replacement of cations by protons. Schematically, the process can be represented as follows:

$$
\begin{gathered}
\mathrm{Mx} /\left(\mathrm{AlO}_{2}\right) \times\left(\mathrm{SiO}_{2}\right) \mathrm{n}-\mathrm{x} /{ }^{\mathrm{x}}+\mathrm{x} / \mathrm{H}_{2} \mathrm{O}+\mathrm{H}^{+} /+\mathrm{H}_{2} \mathrm{O} \rightarrow \\
\text { (the feed zeolite) } \\
\rightarrow /\left(\mathrm{H}_{3} \mathrm{O}\right) \mathrm{x}^{+} /\left(\mathrm{AlO}_{2}\right) \times\left(\mathrm{SiO}_{2}\right) \mathrm{n}-\mathrm{x} /{ }^{x-}+\mathrm{xM}+\mathrm{H}_{2} \mathrm{O} \rightarrow \\
(\text { the hydrogen form }) \\
\rightarrow /(\mathrm{AlOOH}) \times\left(\mathrm{SiO}_{2}\right) \mathrm{n}-\mathrm{x} /+\mathrm{xH}_{2} \mathrm{O} \\
\text { (the hydroxyl form) }
\end{gathered}
$$

It should be noted that the acidic decationation mechanism is quite complicated. In our case of the concentrated solutions, both the cations and anion-forming atoms are simultaneously transferred into the solution. Reactions with dilute acid solutions proceed in two stages: the ion exchange and the dealumination. A proton interacting with the aluminosilicate skeleton of the zeolite leads to the destruction of the cation exchange centers; it happens due to a decrease in the matrix charge during the hydrolysis of aluminum.

It is known that the ion exchange in the adsorbent phase plays the central part in the sorption of heavy metal ions introduced into the system during the enrichment stage, as well as in leaching and migration with groundwater. In the process, the exchange cations of natural zeolites are $\mathrm{Na}, \mathrm{Ca}_{2}, \mathrm{Mg}_{2}$, and, to a small extent, $\mathrm{K}$. This phenomenon is explained by the presence of $\mathrm{K}$ cations in small, cancrinitic cavities. In contrast, the others are located in large cavities of the clinoptilolite's aluminosilicate framework and are easily exchanged for ions present in the environment (Chelishev, 1987).

In the course of the studies, the sorption characteristics of various natural and synthetic zeolites in relation to strontium and cesium radionuclides were also determined in order to evaluate the possibility of using them for the purification of radioactively contami-

\begin{tabular}{|c|c|c|c|c|}
\hline \multirow{2}{*}{ Components } & \multicolumn{4}{|c|}{ Deposits, average content of components, $\%$} \\
\hline & Shivyrtuiskoye & Badinskoye & Kholinskoye & Talan-Gozagorskoye \\
\hline $\mathrm{SiO}_{2}$ & 62.90 & 68.50 & 65.62 & 53.12 \\
\hline $\mathrm{P}_{2} \mathrm{O}_{5}$ & 0.08 & 0.08 & 0.0004 & 0.33 \\
\hline $\mathrm{Al}_{2} \mathrm{O}_{3}$ & 13.61 & 10.57 & 12.21 & 16.63 \\
\hline $\mathrm{TiO}_{2}$ & 0.34 & 0.18 & 0.07 & 1.50 \\
\hline $\mathrm{Fe}_{2} \mathrm{O}_{3}$ & 3.00 & 0.68 & 1.25 & 11.40 \\
\hline $\mathrm{FeO}$ & 0.14 & 0.07 & 0.06 & 0.32 \\
\hline $\mathrm{CaO}$ & 0.61 & 2.52 & 2.07 & 5.82 \\
\hline $\mathrm{MgO}$ & 1.51 & 0.88 & 0.64 & 1.97 \\
\hline $\mathrm{Na}_{2} \mathrm{O}$ & 1.36 & 0.24 & 1.90 & 3.45 \\
\hline $\mathrm{K}_{2} \mathrm{O}$ & 4.04 & 3.12 & 4.14 & 1.78 \\
\hline $\mathrm{S}_{\text {общ. }}$ & 0.007 & $<0.05$ & 0.016 & 0.041 \\
\hline $\mathrm{MnO}$ & 0.11 & 0.03 & 0.14 & 0.08 \\
\hline $\mathrm{H}_{2} \mathrm{O}$ & 3.88 & 5.10 & 3.82 & 1.08 \\
\hline Other impurities & 9.16 & 7.70 & 8.22 & 3.28 \\
\hline
\end{tabular}
nated technogenic and natural waters.

The data presented showed that synthetic and natural zeolites had a specific selectivity toward Cs and $\mathrm{Sr}$ radionuclides. Zeolites were primarily used to

Table 1. The chemical composition of zeolite-containing rocks of East Transbaikalia 
treat low-salt wastewater that does not contain large amounts of competing ions. The sorption of $\mathrm{Cs}$ and $\mathrm{Sr}$ radionuclides occurred most efficiently in the neutral and slightly alkaline medium. The spent sorbent saturated with radionuclides was sent for disposal along with the solid radioactive waste.

In the course of the research, the sorption characteristics were tested of the natural zeolites (clinoptilolites) sampled from the following deposits of the
Transbaikal Territory: Badinskoye - KL (Bad), Kholinskoye - KL (Khol), Shivyrtuiskoye - KL (Shiv), Talan-Gozagorskoye - KL (T-G). The samples differed in the particle size distribution and the enrichment method (the magnetic separation or ultrasonic treatment, or both).

The chemical and mineralogical compositions of zeolites are presented in Tables 1 and 2.

Table 2. Mineral composition of zeolite-containing rocks

\begin{tabular}{|c|c|c|c|c|}
\hline \multirow{2}{*}{ Minerals } & \multicolumn{4}{|c|}{ Deposit, content of mineral phases, $\%$} \\
\hline & Shivyrtuiskoye & Badinskoye & Kholinskoye & Talan-Gozagorskoye \\
\hline Clinoptilolite & $45-65$ & $60-66$ & $63-74$ & - \\
\hline Mordenite & - & - & 7 & - \\
\hline Chabazite & - & - & - & $8-10$ \\
\hline Montmorillonite & $15-20$ & $3-5$ & $3-5$ & $8-10$ \\
\hline Hydromica & $3-5$ & - & - & $2-3$ \\
\hline Quartz & $3-10$ & $3-5$ & $1-3$ & $5-10$ \\
\hline Calcite & $2-5$ & - & - & $\sim 2$ \\
\hline Microcline & $3-5$ & $3-5$ & - & - \\
\hline Plagioclase & - & - & - & \\
\hline Cristobalite & $2-3$ & $10-12$ & $15-18$ & - \\
\hline Pyroxenes & - & - & - & $\sim 21$ \\
\hline X-ray amorphous phase & $<5$ & $10-12$ & $<10$ & - \\
\hline $\begin{array}{l}\text { Phase distribution of iron, \% weight: } \\
\text { Hematite }\end{array}$ & $32.3 / 0.40$ & $6.7 / 0.06$ & $3.8 / 0.02$ & $59.3 / 4.88$ \\
\hline Montmorillonite & $56.4 / 0.71$ & $40 / 0.37$ & $40 / 0.21$ & $9.4 / 0.77$ \\
\hline Hydromica, fine dispersed iron hydroxides & $11.3 / 0.14$ & $53.3 / 0.49$ & $5.62 / 0.30$ & $21.2 / 1.74$ \\
\hline Olivine & - & - & - & $10.1 / 0.83$ \\
\hline
\end{tabular}

Besides the above samples, the following sorbents were used during the tests to obtain the comparative characteristics: clinoptilolites of the Nizhny Trebavets deposits, Slovakia - KL (NT), Bely Plast, Bulgaria - KL (BP), Sokirnitsa, Ukraine - KL (Sok); GL (B) - natural bentonite clay (Belgorod region), NaA - synthetic zeolite type A, TU 2163-003-15285215-2006, an industrial batch, manufactured by the Ishimbay special chemical plant of catalysts (Republic of Bashkortostan), FNS - the inorganic sorbent based on ferrocyanide nickel-potassium deposited on the surface of silica gel, a pilot batch, TU 2641-003-51255813-2007, produced at the IPCE RAS, MDM - the modified manganese dioxide-based sorbent (TU 2641-001-51255813-2007), an industrial batch, produced at the IPCE RAS.

\section{Methods}

Studies on the acidic media neutralization were performed both on the simulated waters, by introducing $0.1 \mathrm{~N} \mathrm{H}_{2} \mathrm{SO}_{4}$ solution to get the $\mathrm{pH}$ required, and on 
real acidified waters of several rare-metal and placer deposits of the Transbaikal Territory. The equilibrium $\mathrm{pH}$ values were attained within the range of 10 to 30 minutes.

Studies of the capability of natural zeolites (Shivyrtuisky and Kholinsky deposits) to selectively adsorb the heavy metal ions were performed at $100 \mathrm{mg} / \mathrm{L}$ concentration of $\mathrm{Cu}^{2+}, \mathrm{Zn}^{2+}, \mathrm{Cd}^{2+}, \mathrm{Ni}^{2+}, \mathrm{Fe}^{3+}$ in the solution.

A modeling approach to the description of the ion exchange on natural zeolites was to consider the ion-exchange equilibrium as a reversible reaction, according to the equation (Bereza A.I., 1985):

$b^{+a}+a B z b \rightarrow b A z a+a B^{+b}$,

where: $a$ - the valency of $A$ ion; $b$ - the valency of $B$ ion; $z$ - the exchangeable part of a zeolite.

The kinetic studies of ion exchange on natural zeolites were important for evaluating the possibility of the application of these minerals for ion exchangers.

The sorption characteristics of the samples in relation to ${ }^{137} \mathrm{Cs}$ and ${ }^{90} \mathrm{Sr}$ radionuclides were determined in batch experiments. An aliquot weight of the air-dry sorbent with the simulated solution containing the tracer amounts of those radionuclides was mixed continuously under static conditions for 48 hours. The mix was filtered through a white ribbon paper filter, and the specific activity of radionuclides was determined in the filtrate. Based on the results of the analysis, the distribution coefficient values $\left(\mathrm{Kd}, \mathrm{cm}^{3} / \mathrm{g}\right)$ of the corresponding radionuclide were calculated according to the formula (1):

$$
K_{d}=\frac{A_{0}-A_{e}}{A_{e}} \times \frac{V_{l}}{m_{s}}
$$

where: $A_{0}, A_{e}$ - the specific activity of the radionuclide in the feed solution and the filtrate, $\mathrm{Bq} / \mathrm{dm}^{3} ; \mathrm{V}_{1}$ - the volume of the liquid phase, $\mathrm{cm}^{3} ; \mathrm{m}_{\mathrm{s}}$ - the sorbent mass, $g$.

The specific activity of ${ }^{137} \mathrm{Cs}$ and ${ }^{90} \mathrm{Sr}$ in solutions was determined by the direct radiometric method with the SKS-50M spectrometric complex (Green Star Technologies, Moscow) using the gamma and beta spectrometric channels, respectively. The samples containing ${ }^{90} \mathrm{Sr}$ were kept for at least 14 days before measurement to establish the radioactive equilibrium of the ${ }^{90} \mathrm{Sr}-{ }^{90} \mathrm{Y}$ pair.

For the sorption of ${ }^{90} \mathrm{Sr}$ from solutions of calcium salts, apart from the values of $\mathrm{K}_{d}{ }^{90} \mathrm{Sr}$, the values of the static exchange capacity (SEC, $\mathrm{mol} / \mathrm{g}$ ) for calcium and the separation coefficient of the $\mathrm{Sr} / \mathrm{Ca}$ pair (DSr/ Ca) were calculated according to formulas 2 and 3 , respectively:

$$
\begin{aligned}
& \text { SEC }=\left(C_{0}-C_{e}\right) \times V_{l} / m_{c}, \\
& D_{\text {Sr } / \mathrm{Ca}}=\left(K_{d} \times C_{e}\right) / S E C,
\end{aligned}
$$

where: $C_{0}, C_{e}$ - the concentration of $\mathrm{Ca}^{2+}$ ions in the feed solution and the filtrate, $\mathrm{mmol} / \mathrm{cm}^{3} ; \mathrm{K}_{\mathrm{d}}$ - the distribution coefficient of ${ }^{90} \mathrm{Sr}, \mathrm{cm}^{3} / \mathrm{g}$.

The concentration of calcium ions in solutions was determined by the volume chelatometry.

\section{Results and Discussion}

\section{Acidified effluent conditioning with natural zeolites}

The experimental study on the possibility of neutralizing acidic media was performed on the simulated waters and real acidified waters by introducing a 0.1 $\mathrm{N} \mathrm{H}_{2} \mathrm{SO}_{4}$ solution to adjust the $\mathrm{pH}$. The neutralization of acidic media was conducted using natural zeolites of the Shivyrtuysky deposit. The time to attain the equilibrium $\mathrm{pH}$ values varied from 10 to 30 minutes. Further increase in the duration time of the natural zeolite interaction did not result in any significant increase in the $\mathrm{pH}$ value. Based on the kinetic curves obtained, the conditional $\mathrm{pH}$ change rate values were determined. The maximum value was observed in the vicinity of $\mathrm{pH}=4$, e.g., in the area corresponding to the effluent acidification. Several factors affected the nature of the changes in the equilibrium $\mathrm{pH}$ values upon the contact with the dispersed phase. The most important where the dispersion of zeolite particles and the liquid-to-solid phase ratio (L/S). The data obtained on the effect of the grain size on the exchange rate unambiguously indicated the diffusion mechanism of the acidic media neutralization process. The process rate increased with the decreased grain diameter of the sorbent and reached the maximum value 
at $D=13.3 \times 10^{2} \mathrm{~m}^{-1}$, at the $\mathrm{S} / \mathrm{L}$ ratio of $\mathrm{S} / \mathrm{L}=0.1$. The application of either larger or smaller fractions reduced the performance by denying the availability of the sorbent surface and the hydrodynamic resistance growth. The values of the exchange capacity and electrokinetic potential were determined to quantify the sorption properties of natural zeolites of the Shivyrtuiskoye deposit (Table 3).

Table 3. Physico-chemical characteristics of the zeolites of the Shivyrtuyskoe deposit

\begin{tabular}{c|c|c|c}
\hline Particle size class, $r 10^{-3}$ & Particle dispersion, $1 / \mathrm{a} 10^{2} \mathrm{~m}^{-1}$ & $\begin{array}{c}\text { Exchange capacity, } \\
\text { mg-eqv/g }\end{array}$ & Potential, $\mathrm{mV}$ \\
\hline$-7.0+4.5$ & 1.74 & 0.84 & \\
\hline$-4.5+2.0$ & 3.08 & 0.86 & -105.6 \\
\hline$-2.0+1.0$ & 6.67 & 0.9 & \\
\hline$-1.0+0.5$ & 13.33 & 1.06 & \\
\hline$-0.5+0$ & 40.00 & 0.86 & \\
\hline
\end{tabular}

It should be noted that the conditional pH change rate, exchange capacity, electrokinetic potential, and sorption capacity by $\mathrm{H}^{+}$were rather high. It could be explained by the peculiarities of the crystal-chemical structure (the large intra-crystalline space volume, the input windows size, the specific surface area, and the composition of the mineral exchange complex).

Sorption of heavy metal cations by natural zeolites

The ion exchange rate in natural zeolites of the Shivyrtuisky and Kholinsky deposits and its dependence on the properties of exchange cations and the structure of the determining minerals were estimated by studying the kinetic dependencies of sorption, based on which the instantaneous adsorption interaction rate values were determined. The analysis of the results showed that under these conditions (the fractional composition of $0.5-1.0 \mathrm{~mm}$, the $S / L$ ratio of $S / L=0.1$, established by the preliminary analysis) the exchange rate was controlled by the intra-diffusion processes. It was significantly increased with the decreasing sorbent grain size and, accordingly, an increase in its surface was determined both by the transition of the cation from the volume to the pores of natural zeolites and by the diffusion inside the entrance windows. Moreover, the experimental data allowed us to evaluate the effect of the structure of natural zeolites on the exchange rate, the values of which were rather high. It was explained by the size of the cavities in the structure of the zeolite.
Analysis of the exchange isotherms of heavy metal cations on natural zeolites indicated the proportional relationship between the specific adsorption and the concentration in a limited range (up to $50 \mathrm{mg} / \mathrm{L}$ ). At that, the selectivity decreased in the clinoptilolitemordenite series.

It should be noted that the cation size had a weak effect on the behavior of $\mathrm{Cd}^{2+}, \mathrm{Zn}^{2+}, \mathrm{Cu}^{2+}, \mathrm{Ni}^{2+}$ ions on natural zeolites of the Shivyrtuisky and Kholinsky deposits. This phenomenon was explained by their physicochemical properties, governed by their electronic structure and, in particular, the presence of an 18-electron outer layer (Chelishev, 1987).

The well-known Freundlich equation described the output sorption curves in the low and medium concentration range:

$G=K \cdot C^{1 / n}$,

where: $\mathrm{G}$ - the specific adsorption, $\mathrm{mg} / \mathrm{g}$; $\mathrm{C}$ - the equilibrium concentration, $\mathrm{mg} / \mathrm{L} ; \mathrm{K}, \mathrm{n}$ - the constants of the sorption process.

Based on the comparison of the equilibrium constants of the ion exchange reactions of heavy metal cations on natural zeolites of the Shivyrtuisky and Kholinsky deposits with a change in the free energy of the system calculated according to the W. Goff equation $\Delta G=-L g \cdot K p$ and by weighing the obtained values one against another, the selectivity series of the high-silicon natural zeolites toward the heavy metal cations 
were drawn as follows: $\mathrm{Cd}^{2+}, \mathrm{Fe}^{3+}>\mathrm{Cu}^{2+}>\mathrm{Zn}^{2+}>\mathrm{Ni}^{2+}$. The series indicated the increase in selectivity with the increase in the ionic radius of the counter-ion.

\section{Sorption of ${ }^{137} \mathrm{Cs}$ from sodium nitrate solutions}

The experiments on the sorption of ${ }^{137} \mathrm{Cs}$ radionuclide were conducted from 0.1 and $1.0 \mathrm{~mol} / \mathrm{dm}^{3} \mathrm{NaNO}_{3}$ solutions at $\mathrm{pH}=6.0$. The solid-to-liquid phase ratio (S/L) was 1/200, and the contact time was 48 hours. In all cases, the sorbent fractions with the grain size of less than $0.2 \mathrm{~mm}$ were used. The results are shown in Table 4. From this point on, the $K_{d}$ values given were an average of two or three parallel experiments.
Table 4 shows that among the studied samples of natural clinoptilolites, the clinoptilolite of the Talan-Gozagorskoe deposit had the best sorption characteristics in relation to ${ }^{137} \mathrm{Cs}$. All other clinoptilolites revealed approximately the same sorption characteristics. The natural bentonite clay had significantly higher sorption characteristics concerning ${ }^{137} \mathrm{Cs}$ in low-salt solutions. The synthetic ferrocyanide sorbent of the FNS brand showed the maximum selectivity for cesium, the $\mathrm{Kd}^{137} \mathrm{C}$ s value on which was $2-3$ orders of magnitude higher than for all of the other studied sorbents.

Table 4. The distribution coefficient $\left(\mathrm{K}_{d}\right)$ values of ${ }^{137} \mathrm{Cs}$ on various samples of sorbents after the sorption from 0.1 and $1.0 \mathrm{~mol} / \mathrm{dm}^{3} \mathrm{NaNO}_{3}$ solution

\begin{tabular}{|c|c|c|}
\hline \multirow{2}{*}{$\begin{array}{l}\text { Name } \\
\text { sample }\end{array}$} & \multicolumn{2}{|c|}{$\mathrm{K}_{\mathrm{d}}$ values of ${ }^{137} \mathrm{Cs}, \mathrm{cm}^{3} / \mathrm{g}$ upon the sorption from solution } \\
\hline & $0.1 \mathrm{~mol} / \mathrm{dm}^{3} \mathrm{NaNO}_{3}$ & $1.0 \mathrm{~mol} / \mathrm{dm}^{3} \mathrm{NaNO}_{3}$ \\
\hline KL (Bad) & $2,210 \pm 90$ & $131 \pm 3$ \\
\hline $\mathrm{KL}(\mathrm{Hol})$ & $1,780 \pm 50$ & $64 \pm 3$ \\
\hline KL (Shiv) & $1,590 \pm 40$ & $81 \pm 4$ \\
\hline $\mathrm{KL}(\mathrm{T}-\mathrm{G})$ & $1,930 \pm 50$ & $826 \pm 4$ \\
\hline KL (NT) & $1,310 \pm 60$ & $106 \pm 4$ \\
\hline $\mathrm{KL}(\mathrm{BP})$ & $2,080 \pm 50$ & $127 \pm 3$ \\
\hline $\mathrm{KL}$ (Soc) & $1,600 \pm 80$ & $115 \pm 9$ \\
\hline $\mathrm{GL}(\mathrm{B})$ & $13,000 \pm 2000$ & $365 \pm 5$ \\
\hline $\mathrm{NaA}$ & $680 \pm 20$ & $20 \pm 2$ \\
\hline FNS & $84,000 \pm 2500$ & $60,000 \pm 2000$ \\
\hline
\end{tabular}

\section{Sorption of ${ }^{90} \mathrm{Sr}$ radionuclide and $\mathrm{Ca}^{2+}$ ions}

For the sorption of ${ }^{90} \mathrm{Sr}$ and $\mathrm{Ca}^{2+}$ ions, a simulated calcium chloride solution with $0.01 \mathrm{~mol} / \mathrm{dm}^{3}$ concentration of calcium and $\mathrm{pH}=6.0$ was used as the liquid phase. Before the experiments, the tracer amount of ${ }^{90} \mathrm{Sr}$ radionuclide of about $10^{5} \mathrm{~Bq} / \mathrm{dm}^{3}$ was added into the solution.

The obtained values of the static exchange capacity (SEC) for $\mathrm{Ca}^{2+}$, the distribution coefficient $\left(\mathrm{K}_{\mathrm{d}}\right)$ of ${ }^{90} \mathrm{Sr}$, and the separation coefficient of the $\mathrm{Sr} / \mathrm{Ca}$ ( $\mathrm{DSr} / \mathrm{Ca}$ ) pair on the studied sorbent samples are given in Table 5.
Table 5 shows that among the studied samples of the natural clinoptilolites, the clinoptilolite of the Badinsky deposit had the best sorption characteristics concerning ${ }^{90} \mathrm{Sr}\left(\mathrm{K}_{\mathrm{d}}\right.$ of $\left.{ }^{90} \mathrm{Sr}=1,120 \mathrm{~cm}^{3} / \mathrm{g}\right)$. The clinoptilolites of the Bely Plast (Bulgaria) and Sokirnitsa deposits (Ukraine) have $K_{d}$ of ${ }^{90} \mathrm{Sr}$ equal to 530 and $360 \mathrm{~cm}^{3} / \mathrm{g}$, respectively. The remaining clinoptilolite samples had significantly lower sorption characteristics $\left(K_{d}\right.$ of ${ }^{90} \mathrm{Sr}=65-205$ $\mathrm{cm}^{3} / \mathrm{g}$ ). With ${ }^{90} \mathrm{Sr}$, the natural clinoptilolites were significantly inferior in their sorption-selective characteristics to the industrial MDM and $\mathrm{NaA}$ sorbents. 
Table 5. The values of the static exchange capacity (SEC) for $\mathrm{Ca}^{2+}$, the distribution coefficient $\left(\mathrm{K}_{d}\right)$ for ${ }^{90} \mathrm{Sr}$, and the separation coefficient of the $\mathrm{Sr} / \mathrm{Ca}$ pair (DSr/Ca) on different sorbent samples $\left(0.01 \mathrm{~mol} / \mathrm{dm}^{3} \mathrm{CaCl}_{2}\right.$ solution, $\mathrm{pH}=6.0, \mathrm{~S} / \mathrm{L}=1 / 200$ )

\begin{tabular}{|c|c|c|c|}
\hline $\begin{array}{l}\text { Name } \\
\text { Sample }\end{array}$ & $\mathrm{SEC}$ for $\mathrm{Ca}^{2+}, \mathrm{mmol} / \mathrm{g}$ & $\mathrm{K}_{\mathrm{d}}$ of ${ }^{90} \mathrm{Sr}, \mathrm{cm}^{3} / \mathrm{g}$ & $\mathrm{D}_{\mathrm{Sr} / \mathrm{Ca}}$ \\
\hline $\mathrm{KL}(\mathrm{Bad})$ & 0.82 & $1,120 \pm 50$ & 9.0 \\
\hline $\mathrm{KL}(\mathrm{Hol})$ & 0.74 & $185 \pm 5$ & 1.8 \\
\hline KL (Shiv) & 0.43 & $205 \pm 5$ & 4.2 \\
\hline $\mathrm{KL}(\mathrm{T}-\mathrm{G})$ & 0.45 & $65 \pm 4$ & 1.3 \\
\hline $\mathrm{KL}(\mathrm{NT})$ & $<0.01$ & $175 \pm 5$ & - \\
\hline $\mathrm{KL}(\mathrm{BP})$ & 0.038 & $530 \pm 10$ & 49 \\
\hline $\mathrm{KL}$ (Soc) & 0.24 & $360 \pm 10$ & 14.4 \\
\hline $\mathrm{GL}(\mathrm{B})$ & $<0.01$ & $40 \pm 2$ & - \\
\hline MDM & 0.96 & $8,600 \pm 100$ & 56 \\
\hline $\mathrm{NaA}$ & 1.65 & $4,400 \pm 50$ & 4.7 \\
\hline
\end{tabular}

\section{Conclusions}

It was experimentally shown that the acidic media's neutralizing process rate with natural zeolites increased with the decreasing sorbent grain diameter and reached the maximum value, which explained the reason for using the fine-grained sorbents. The results obtained during the experimental studies made it possible to evaluate the hydrolytic peculiarities of the natural zeolites of the Shivyrtuysky deposit and to determine the optimal parameters for the neutralization of oxidized waters: $S / L=0.1-0.2$, the fractional particle size distribution of natural zeolites of $0.5-1.0 \mathrm{~mm}$, the contact time within the range of 10-30 minutes.

The comparative study of the ion exchange kinetics on the high-silicon natural zeolites of East Transbaikalia, the obtained isotherms and accordingly calculated values of the change in the free energy of the system, and the constants of the sorption process allowed us to estimate the rate of exchange reactions of heavy metal cations on the zeolites, as a function of their properties and structure.

All the studied samples of the natural zeolites of the Transbaikal Territory had a high sorption activity concerning ${ }^{137} \mathrm{Cs}$ radionuclide in low-salt solutions. They could be used as efficient sorbents for the purification of the low-saline wastewater and natural waters from ${ }^{137} \mathrm{Cs}$. Among the natural clinoptilolite samples, the clinoptilolite of the Talan-Gozagorsky deposit of the Chita region had the best sorption characteristics in relation to ${ }^{137} \mathrm{Cs}$.

So far as ${ }^{90} \mathrm{Sr}$ was concerned, the clinoptilolite of the Badinsky deposit showed the best sorption characteristics among the Transbaikal Territory's natural clinoptilolites. It could be used as a sorbent for the comprehensive removal of ${ }^{137} \mathrm{Cs}$ and ${ }^{90} \mathrm{Sr}$ from low-mineralized wastewater and natural waters.

However, natural clinoptilolites in their sorption-selective characteristics were significantly inferior to the industrial sorbents: FNS (for cesium) and $\mathrm{NaA}$ and MDM (for strontium).

\section{Acknowledgments}

This work was carried out as a part of the project of the Federal State Property Inspection No. Registration AAAA-A17-117092750073-6.\{Gurauskiene, 2006, Eco-design methodology for electrical and electronic equipment industry\} 


\section{References}

Saneev B.G., Ivanova I.Y., Tuguzova T.F., Frank M.I. (2011) Prioritety ispolzovania atomnih stantsii maloy moshnosty na Vostoke Rossii (Priorities for the use of low power nuclear power plants in the East of Russia). Атомная энергия 111(5): 276-281. https://doi.org/10.1007/s10512-012-9501-1

Melnikov N.N., Amosov P.V., Gusak S.A., Novozhilova N.V., Klimin S.G. (2014) Otsenka teplovogo vozdeistvia atomnoy stantsii maloy moshnosty na mnogoletnemiorzlie gornie porodi (Assessment of the thermal effect of a low-power underground nuclear power plant on permafrost rocks). Arctica: ecologia I economica 1(13): 30-37.

Melnikov N.N., Amosov P.V., Klimin S.G., Novozhilova N.V. (2015) Atomnie stantsii maloy moshnosty dlia otdalionnih raionov strani: problem bezopasnosty (Low Power Nuclear Power Plants for Remote Areas of the Country: Security Concerns). Inzhenernaya zashita 4(9): 55-63

Kuznetsov Y.V., Shebetkovskiy V.N., Trusov A.G. (1974) Osnovy ochistky vody ot radioaktivnih zagriazneniy (Basics of water purification from radioactive contamination). Атомиздат. 366 p.

Ryabchikov B.E. (2008) Ochistka zhidkih radioaktivnih othodov (Liquid radioactive waste treatment). Dely print. $516 \mathrm{p}$.

Milyutin V.V., Gelis V.M., Penzin R.A. (1993) Sorbtsionno-selectivnie harakteristiky neorganicheskih sorbentov I ionoobmennih smol po otnosheniyu $k$ tseziyu i strontsiyu (Sorption-selective characteristics of inorganic sorbents and ion-exchange resins with respect to cesium and strontium). Radiohimiya. 35(3) 76-78.

Milyutin V.V., Gelis V.M., Nekrasova N.A., Kononenko O.A. (2012) Issledovaniye sorbtsii radionuklidov tseziya, strontsiya, urana i plutoniya na prirodnih I modifitsirovannih glinah (Study of sorption of radionuclides of cesium, strontium, uranium and plutonium on natural and modified clays). Radiohimiya. 54(1) 71-74.

Pavlenko Y.V. (2000) tseolitovie mestorozhdeniya Vostochnogo Zabaikaliya (Zeolite deposits of East Transbaikalia). Publishing House of the Chita State University 101 p.

Khatkova A.N., Razmakhnin K.K. (2014) Otsenka vozmozhnosty kompleksnoy pererabotky tseolitsoderzhashego sirya (Assessment of the possibility of complex processing of zeolite-containing raw materials). Razvedka I ohrana nedr. 6, 48-49

Shushkov D.A., Kotova O.B., Kapitanov V.M., Ignatiev A.N. (2006) Analtsimsoderzhashiye porody Timana kak perspectivniy vid poleznih iskopaemih (Timan analytic rocks as a promising type of mineral). Nauchnie recomendatsii - narodnomu hoziaistvu, Siktivkar, 123, p 40.

Chelishev N.F. (1987) Tseolity - noviy tip mineralnogo sirya (Zeolites - a new type of mineral raw materials). Nedra. 176 p.

Bereza A.I., Rudik T.G. (1985) Sravneniye sorbtsionnih svoistv tseolitov otdelnih mestorozhdeniy Sibiri I dalnego Vostoka (Comparison of the sorption properties of zeolites of individual deposits in Siberia and the Far East). Izvestiia Vuzov, stroitelstvo i arhitectura, 107-141.

Yusupov T.S. (1985) Sposobi kontsentrirovaniya I videleniya tseolitov iz gornih porod (Methods of concentration and separation of zeolites from rocks). Metodi diagnostiki i kolichestvennogo opredeleniya soderzhaniya tseolitov $v$ gornih porodah. Publishing House of the Institute of Geology and Geophysics, Siberian Branch of the USSR Academy of Sciences, Novosibirsk, 161-168. 